Proc. Indian Acad. Sci. (Chem. Sci.), Vol. 112, No. 1, February 2000, pp. 1-17

(C) Indian Academy of Sciences

\title{
Cobalt(III), nickel(II) and ruthenium(II) complexes of 1,10-phenanthroline family of ligands: DNA binding and photocleavage studies
}

\author{
S AROUNAGUIRI ${ }^{\mathrm{a}}$, D EASWARAMOORTHY ${ }^{\mathrm{a}+}$, A ASHOKKUMAR ${ }^{\mathrm{a}}$, \\ APARNA DATTAGUPTA ${ }^{\mathrm{b}}$ and BHASKAR G MAIYA ${ }^{\mathrm{a} *}$ \\ ${ }^{a}$ School of Chemistry and \\ ${ }^{\mathrm{b}}$ School of Life Sciences, University of Hyderabad, Hyderabad 500 046, India \\ ${ }^{+}$Permanent address: Department of Chemistry, Crescent Engineering College, \\ Chennai 600 048, India \\ e-mail: bgmsc@uohyd.ernet.in
}

MS received 11 October 1999

\begin{abstract}
DNA binding and photocleavage characteristics of a series of mixedligand complexes of the type $\left[\mathrm{M}(\mathrm{phen})_{2} \mathrm{LL}\right]^{\mathrm{n}+}$ (where $\mathrm{M}=\mathrm{Co}(\mathrm{III}), \mathrm{Ni}(\mathrm{II})$ or $\mathrm{Ru}(\mathrm{II})$, $\mathrm{LL}=1,10$-phenanthroline (phen), phenanthroline-dione (phen-dione) or dipyridophenazine (dppz) and $n=3$ or 2 ) have been investigated in detail. Various physico-chemical and biochemical techniques including UV/Visible, fluorescence and viscometric titration, thermal denaturation, and differential pulse voltammetry have been employed to probe the details of DNA binding by these complexes; intrinsic binding constants $\left(K_{b}\right)$ have been estimated under a similar set of experimental conditions. Analysis of the results suggests that intercalative ability of the coordinated ligands varies as dppz > phen > phen-dione in this series of complexes. While the $\mathrm{Co}(\mathrm{II})$ and $\mathrm{Ru}(\mathrm{II})$ complexes investigated in this study effect photocleavage of the supercoiled pBR 322 DNA, the corresponding Ni(II) complexes are found to be inactive under similar experimental conditions. Results of detailed investigations carried out inquiring into the mechanistic aspects of DNA photocleavage by $\left[\mathrm{Co}(\text { phen })_{2}(\mathrm{dppz})\right]^{3+}$ have also been reported.
\end{abstract}

Keywords. Phenanthroline family of ligands; metal complexes; DNA binding and photocleavage.

\section{Introduction}

Current burgeoning interest in small molecules that are capable of binding and cleaving DNA is related to their utility in the design and development of synthetic restriction enzymes, new drugs, DNA footprinting agents etc. and also to their ability to probe the structure of DNA itself ${ }^{1,2}$. In this regard, metal complexes have been found to be particularly useful because of their potential to bind DNA via a multitude of interactions and to cleave the duplex by virtue of their intrinsic chemical, electrochemical and photochemical reactivities ${ }^{3-10}$. Prominent among the various metal complexes employed so far in studies with DNA are those metallo-intercalators which incorporate either 1,10phenanthroline (phen) or a modified phenanthroline moiety as a ligand. A singular

*For correspondence 
advantage in using these metallo-intercalators for such studies is that the ligands or the metal in them can be varied in an easily controlled manner to facilitate an individual application.

We have been interested to know the effect of variation of the metal ion and also the ligand on the ability to bind and photocleave DNA in mixed ligand complexes containing the phenanthroline family of ligands ${ }^{11-13}$. During our studies, it occurred to us that complexes of the type $\left[\mathrm{M}(\mathrm{phen})_{2}(\mathrm{LL})\right]^{\mathrm{n}+}$ where $\mathrm{M}$ is a transition metal ion and LL is a modified phenanthroline ligand are well-suited for this purpose. Although DNA interactions of a number of $\left[\mathrm{M}(\mathrm{phen})_{2}(\mathrm{LL})\right]^{\mathrm{nt}}$ type complexes have previously appeared in the literature, relatively less attention seems to have been paid to systematic investigations inquiring into the effects brought about by changing $\mathrm{M}$ and LL in such complexes. In this paper, we compare the DNA binding and photocleavage characteristics of a family of $\left[\mathrm{M}(\mathrm{phen})_{2}(\mathrm{LL})\right]^{\mathrm{n}+}$ type complexes $(\mathrm{M}=\mathrm{Co}(\mathrm{III}), \mathrm{Ni}(\mathrm{II})$ or $\mathrm{Ru}(\mathrm{II}), \quad \mathrm{LL}=$ phen, phenanthroline-dione (phen-dione) or dipyridophenazine (dppz) and $n=3$ or 2) (figure 1). Various physico-chemical and biochemical techniques including UV/Visible-, fluorescence-, and viscometric titration, thermal denaturation, differential pulse voltammetry and gel electrophoresis have been utilized to probe the nature of interaction of these complexes with the duplex. Also reported in this paper is a detailed mechanistic investigation on the DNA photocleavage by $\left[\mathrm{Co}(\mathrm{phen})_{2}(\mathrm{dppz})\right]^{3+}$.

\section{Experimental}

All common chemicals, solvents as well as cobalt(II), nickel(II) and ruthenium(III) salts, 1,10-phenanthroline monohydrate and 1,2-diaminobenzene were purchased either from BDH (Mumbai, India) or Merck (Mumbai, India). All the solvents were purified before use as per the standard procedures ${ }^{14}$. Deionized, triply distilled water was used for preparing various buffers. Calf thymus DNA (CT DNA), 1,4-diazabicyclo(2.2.2.)octane $(\mathrm{DABCO})$, superoxide dismutase (SOD), phenyl-t-butylnitrone $(\mathrm{PBN}), \mathrm{D}_{2} \mathrm{O}$, tetrabutylammonium chloride ( $\mathrm{TBACl}$ ) and tetrabutylammonium hexafluorophosphate $\left(\mathrm{TBAPF}_{6}\right)$ were obtained from Sigma Chemicals, USA. The supercoiled pBR 322 DNA ( $\mathrm{CsCl}$ purified, Bangalore Genie, Bangalore, India) was used as received. Agarose

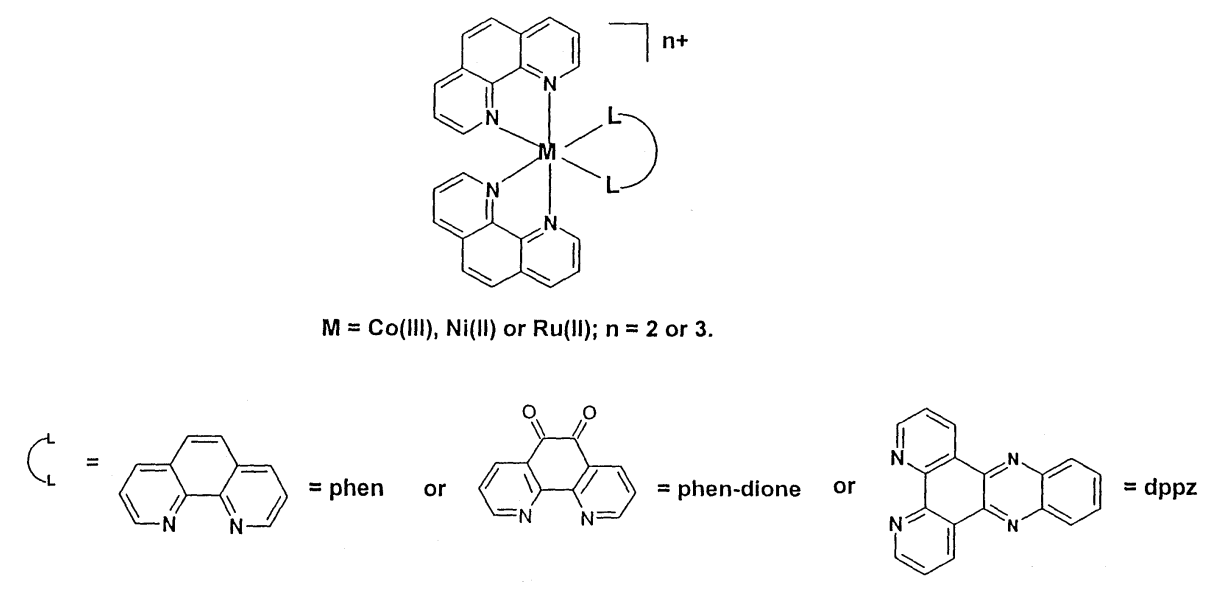

Figure 1. Structures of the $\left[\mathrm{M}(\mathrm{phen})_{2}(\mathrm{LL})\right]^{\mathrm{n}+}$ type complexes investigated in this study. 
(molecular biology grade) and ethidium bromide (EtBr) were purchased from Bio-Rad, USA.

\subsection{Synthesis}

Ligands phen-dione and dppz were synthesized as per the reported procedures ${ }^{15,16}$ $\left[\mathrm{Co}(\text { phen })_{3}\right]^{3+17}, \quad\left[\mathrm{Co}(\text { phen })_{2} \mathrm{Cl}_{2}\right]^{18}, \quad\left[\mathrm{Co}(\text { phen })_{2} \mathrm{Cl}_{2}\right]^{+19}, \quad\left[\mathrm{Co}(\text { phen })_{2}(\text { phen-dione })\right]^{2+20}$, $\left[\mathrm{Co}(\text { phen })_{2}(\mathrm{dppz})\right]^{2+11}, \quad\left[\mathrm{Ni}(\text { phen })_{3}\right]^{2+21}, \quad\left[\mathrm{Ni}(\text { phen })_{2} \mathrm{Cl}_{2}\right]^{22}, \quad\left[\mathrm{Ni}(\mathrm{phen})_{2} \quad(\mathrm{dppz})\right]^{2+11}$, $\left[\mathrm{Ru}(\text { phen })_{3}\right]^{3+23}, \quad\left[\mathrm{Ru}(\text { phen })_{2} \mathrm{Cl}_{2}\right]^{24}, \quad\left[\mathrm{Ru}(\text { phen })_{2}(\text { phen-dione })\right]^{2+25}$ and $\left[\mathrm{Ru}(\text { phen })_{2}\right.$ $(\mathrm{dppz})]^{2+25,26}$ were prepared employing methods available in the literature. $\left[\mathrm{Ni}(\text { phen })_{2} \text { (phen-dione) }\right]^{2+}$ was prepared following a procedure analogous to that adopted for the synthesis of $\left[\mathrm{Ru}(\mathrm{phen})_{2}(\text { phen-dione })\right]^{2+25}$. The hexafluorophosphate salts of the synthesized complexes have been recrystallized by dissolving them in the minimum volume of acetone and reprecipitating, after filtration, by the addition of ether. All these complexes gave correct elemental analysis consistent with their molecular formulae.

The hexafluorophosphate salts of the complexes have been converted to the watersoluble, chloride salts by treating the former salt solutions with excess $\mathrm{TBACl}$ in acetone. The chloride salts, being insoluble in acetone, were instantaneously precipitated out of the solution. They were filtered and vacuum dried before use.

\subsection{Physical methods}

UV/Visible and IR spectra were recorded with a Shimadzu model UV-160 A (coupled with a temperature controller Model TCC-240A) and a JASCO Model 5300 FT-IR spectrophotometer, respectively. Fluorescence spectra were recorded with a JASCO Model 7700 spectrofluorometer for solutions having an absorbance less than 0.2 at the excitation wavelength. $\left[\mathrm{Ru}(\mathrm{phen})_{3}\right]^{2+}$ was used as the standard for this purpose $(\phi,=0.028$ in $\mathrm{CH}_{3} \mathrm{CN}$ ) ${ }^{27}$. ${ }^{1} \mathrm{H}$ NMR spectra were recorded with a Bruker NR-FT 200 spectrometer using DMSO- $d_{6} / \mathrm{CDCl}_{3}$ as the solvent and tetramethylsilane (TMS) as an internal standard. ESR spectra were recorded with JEOL JM-FE3X spectrometer with diphenylpicrylhydrazide (DPPH) as an ESR standard. Magnetic susceptibility measurements for solid samples of the complexes were carried out using a Cahn Instruments (Model 6612) system. $\mathrm{CuSO}_{4}$ and $\mathrm{Hg}\left[\mathrm{Co}(\mathrm{CNS})_{4}\right]$ were employed as magnetic susceptibility standards. Diamagnetic corrections to the apparent magnetic susceptibility values have been incorporated, as specified ${ }^{28}$. Cyclic voltammetric and differential pulse voltammetric experiments were performed on a Princeton Applied Research (PAR) 174A polarographic analyzer coupled with a PAR 175 universal programmer and a PAR RE $0074 X-Y$ recorder. A platinum-button working electrode, a platinum-wire counter electrode and a saturated calomel reference electrode (SCE) were employed for experiments involving the nonaqueous solvents $\left(\mathrm{PF}_{6}\right.$ salts of the complexes). The SCE was separated from the deaerated $\left(\mathrm{N}_{2}\right)$ bulk electrolytic solution by a fritted-glass-discjunction containing the solvent $\left(\mathrm{CH}_{3} \mathrm{CN}\right)$ and the supporting electrolyte $\left(\mathrm{TBAPF}_{6}\right)$. Ferrocene was used as an internal standard for these experiments.

\subsection{Studies with DNA}

Concentration of CT DNA was measured by using its known extinction coefficient at $260 \mathrm{~nm}\left(6600 \mathrm{M}^{-1} \mathrm{~cm}^{-1}\right)^{29}$. BufferA $(5 \mathrm{mM}$ tris, $p \mathrm{H} 7 \cdot 1,50 \mathrm{mM} \mathrm{NaCl})$ was used for 
absorption titration experiments and luminescence measurements, bufferB (1 mM phosphate, $p \mathrm{H} 7 \cdot 0,2 \mathrm{mM} \mathrm{NaCl}$ ) was used for thermal denaturation and differential-pulse voltammetric experiments. BufferC $\left(1.5 \mathrm{mM} \mathrm{Na} \mathrm{HPO}_{4}, 0.5 \mathrm{mM} \mathrm{NaH} \mathrm{PO}_{4}, 0.25 \mathrm{mM}\right.$ $\mathrm{Na}_{2}$ EDTA, $p \mathrm{H}=7 \cdot 0$ ) was used for the viscometric titrations. The chloride salts of the complexes were used in studies with DNA.

2.3a Absorption titration experiments: These experiments were performed by maintaining a constant concentration of the complex while varying the nucleic acid concentration. This was achieved by dissolving an appropriate amount of the metal complex in the DNA stock solution and by mixing various proportions of the metal complex and DNA stock solutions while maintaining the total volume constant $(1 \mathrm{ml})$. This resulted in a series of solutions with varying concentrations of DNA but with a constant concentration of the complex. The absorbance $(A)$ of the most red-shifted band of each investigated complex was recorded after successive additions of CT DNA. The intrinsic binding constant, $K_{b}$, was determined from the plot of [DNA] $/\left(\varepsilon_{a}-\varepsilon_{f}\right)$ vs [DNA], where [DNA] is the concentration of DNA in base pairs, $\varepsilon_{a}$, the apparent extinction coefficient is obtained by calculating $A_{\text {obsd }} /\left[\right.$ complex] and $\varepsilon_{f}$ corresponds to the extinction coefficient of the complex in its free form. The data were fitted to (1) where $\varepsilon_{b}$ refers to the extinction coefficient of the complex in the fully bound form.

$$
[\mathrm{DNA}] /\left(\varepsilon_{a}-\varepsilon_{f}\right)=[\mathrm{DNA}] /\left(\varepsilon_{b}-\varepsilon_{f}\right)+1 / K_{b}\left(\varepsilon_{b}-\varepsilon_{f}\right) .
$$

Each set of data, when fitted to the above equation, gave a straight line with a slope of $1 /\left(\varepsilon_{b}-\varepsilon_{f}\right)$ and a $y$-intercept of $1 / K_{b}\left(\varepsilon_{b}-\varepsilon_{f}\right) . K_{b}$ was determined from the ratio of the slope to intercept. An in-house nonlinear least square analysis program or the MicroCal Origin software package run on an IBM-compatible Pentium 166 computer was used for curvefitting the data.

2.3b Fluorescence titration experiments: A procedure analogous to that used for the absorption titration experiment was used in these experiments. The concentration of the $\mathrm{Ru}$ (II) complex employed, however, was between about $10^{-6}$ and $10^{-5} \mathrm{M}$ and that of DNA was between about $10^{-6}$ and $10^{-3} \mathrm{M}$ (base pairs).

2.3c Thermal denaturation studies: DNA melting experiments were carried out by monitoring the absorption $(260 \mathrm{~nm})$ of CT DNA $(160 \mu \mathrm{M})$ at various temperatures, in both the absence and the presence $(0-10 \mu \mathrm{M})$ of each investigated complex. The melting temperature $\left(T_{m}\right)$ and the curve width $\sigma_{T}$ (= temperature range between which $10 \%$ to $90 \%$ of the absorption increase occurred) were calculated as described ${ }^{30}$. The shape of the melting curves, $T_{m}$ and $\sigma_{T}$ values for CT-DNA and for CT-DNA in the presence of $\left[\mathrm{Ru}(\mathrm{phen})_{3}\right]^{2+}$ were consistent with the literature data ${ }^{30}$. Some of the metal complexes were seen to absorb at $260 \mathrm{~nm}$, but control experiments suggested that this absorption is independent of temperature.

2.3d Viscometry: Viscometric titrations were performed with a Canhon-Ubblehode viscometer at $25 \pm 1^{\circ} \mathrm{C}$. Each compound $(3-40 \mu \mathrm{M})$ was introduced into the degassed DNA solution ( $300 \mu \mathrm{M}$ in base-pairs) present in the viscometer using a Hamilton syringe fitted with a glass extender. Mixing of the drug and DNA was done by bubbling with 
nitrogen. Flow times were measured, using a digital stop-watch, at least thrice and were accepted if they agreed within $0 \cdot 1 \mathrm{~s}$. Reduced specific viscosity was calculated according to Cohen and Eisenberg ${ }^{31}$. Plots of $\eta / \eta_{\mathrm{o}}\left(\eta\right.$ and $\eta_{\mathrm{o}}$ are the reduced specific viscosities of DNA in the presence and absence of the drug) versus [drug]/[DNA] were constructed. Plot of $\eta / \eta_{\mathrm{o}}$ versus $[\mathrm{EtBr}] /[\mathrm{DNA}]$ was found to be similar to that reported in the literature ${ }^{32}$.

2.3e Differential pulse voltammetry: Differential pulse voltammetric experiments were performed for $0.1 \mathrm{mM}$ chloride salts of the cobalt(III) complexes in the presence and absence of 0-3 mM (base-pairs) CT-DNA. The working electrode used was made up of glassy carbon and it was polished prior to each voltammetric run with $0.25 \mu \mathrm{m}$ diamond paste on a nylon buffing pad and then subjected to ultrasonic cleaning for $\approx 5 \mathrm{~min}$ in $95 \%$ ethanol. Both, the peak currents and the peak potentials, were reproducible to better than $10 \%$ under our experimental conditions ${ }^{33,34}$.

2.3f Gel electrophoresis: For the gel electrophoresis experiments, supercoiled pBR 322 DNA $(100 \mu \mathrm{M})$ in tris- $\mathrm{HCl}$ buffer $(p \mathrm{H}=8.0)$ was treated with an $10-100 \mu \mathrm{M}$ of the metal complex and the mixture was incubated for $1 \mathrm{~h}$ in the dark. The samples were then analyzed by $0.8 \%$ agarose gel electrophoresis (tris-acetic acid-EDTA buffer, $p \mathrm{H}=8.0$ ) at $40 \mathrm{~V}$ for $5 \mathrm{~h}$. The gel was stained with $1 \mu \mathrm{g} / \mathrm{ml}$ ethidium bromide for $0.5 \mathrm{~h}$ after which it was analyzed using the UVP gel documentation system GDS 2000 and was also directly photographed and developed as described previously ${ }^{11,12,35,36}$. Irradiation experiments were carried out by keeping the pre-incubated (dark, $1 \mathrm{~h}$ ) samples inside the sample chamber of a JASCO Model FP-7700 spectrofluorometer. The excitation wavelength was either $313 \pm 5$ or $350 \pm 5 \mathrm{~nm}$ for the $\mathrm{Co}$ (III) and $\mathrm{Ni}$ (II) salts and $450 \pm 5 \mathrm{~nm}$ for the $\mathrm{Ru}$ (II) complexes.

2.3g Spin trapping studies: These experiments were carried out for irradiated (> 350 nm, 150 W Xenon arc lamp, 5-60 s irradiation time) solutions containing $\left[\mathrm{Co}(\text { phen })_{2}(\mathrm{dppz})\right]^{3+}$ and PBN. 'On-line' ESR spectra of the samples were recorded during irradiation.

Unless otherwise specified, all the experiments were carried out at $293 \pm 3 \mathrm{~K}$.

\section{Results and discussion}

Although a few among the investigated complexes have previously been spectrally characterized to their structure ${ }^{17-26}$, this study has provided an opportunity to compare the spectroscopic and other physical properties of all the complexes by using data obtained under the similar set of experimental conditions. In addition, during the course of this study it was found necessary to compile and compare the physico-chemical characteristics of each investigated complex in order to choose the appropriate technique for probing the DNA interaction. Thus, we compare the physical and spectroscopic characteristics of the investigated $\mathrm{Co}(\mathrm{III}), \mathrm{Ni}(\mathrm{II})$ and $\mathrm{Ru}(\mathrm{II})$ complexes before we discuss their DNA binding and photocleavage properties.

As far as the DNA interactions of these complexes are concerned, DNA binding by $\left[\mathrm{M}(\mathrm{phen})_{3}\right]^{\mathrm{n}+}(\mathrm{M}=\mathrm{Co}(\mathrm{III})$ or $\mathrm{Ru}(\mathrm{II})$ and $n=2$ or 3$)$ and $\left[\mathrm{Ru}(\mathrm{phen})_{2}(\mathrm{dppz})\right]^{2+}$ have been investigated in great detail by several groups ${ }^{3,6,10,30,37-39}$ and that of $\left[\mathrm{M}(\mathrm{phen})_{2}(\mathrm{dppz})\right]^{\mathrm{n}+}$ ( $\mathrm{M}=\mathrm{Co}(\mathrm{III})$ or $\mathrm{Ni}(\mathrm{II})$ and $n=2$ or 3 ) by us in lesser detail ${ }^{11}$. However, relatively few 
studies seem to have been attempted to investigate the effect of variation of the metal ion and also the ligand on the ability to bind and photocleave DNA in mixed ligand complexes containing the phenanthroline family of ligands. In the present study, we have endeavoured to compare the DNA binding and photocleavage properties of a series of $\left[\mathrm{M}(\mathrm{phen})_{2}(\mathrm{LL})\right]^{2+}$ type complexes under similar experimental conditions.

\subsection{Spectroscopic characterization}

The hexafluorophosphate salts of the complexes employed in this work have been fully characterized by UV/Visible, IR and ${ }^{1} \mathrm{H}$ NMR spectroscopic (for diamagnetic complexes) and magnetic susceptibility (for paramagnetic complexes) measurements. These data summarized in tables 1 and 2 agree well with the reported values, in cases where applicable ${ }^{11,17-26}$.

Whereas $\mathrm{Co}(\mathrm{III})$ and $\mathrm{Ru}(\mathrm{II})$ complexes were found to be diamagnetic and hence were amenable for characterization by the ${ }^{1} \mathrm{H}$ NMR method, magnetic susceptibility data for nickel complexes clearly show that the metal ion is in the $2+$ oxidation state in these complexes (table 2). The IR spectra of phen-dione clearly exhibits a band in the region of $1703 \pm 2 \mathrm{~cm}^{-1}$ that is ascribable to a stretching frequency of the $\mathrm{C}=\mathrm{O}$ bonds on the ligand. This band was seen to be not shifted much in the corresponding complexes (table 1), which is reasonable since the $\mathrm{C}=\mathrm{O}$ moieties are far removed from the site of coordination of this ligand with the metal. The UV/Visible spectral data of all the nine complexes investigated in this study are summarized in table 1 . Based on the literature data on the spectral properties of phen, phen-dione, dppz and the various other complexes containing these ligands ${ }^{15-27,40}$, bands appearing in the spectra of the $\mathrm{Co}$ (III) and $\mathrm{Ni}(\mathrm{II})$ complexes can be assigned exclusively to the intraligand transitions. The ruthenium(II) complexes,

Table 1. UV/Visible and IR data.

\begin{tabular}{lll}
\hline Complex & \multicolumn{1}{c}{ UV-visible $\lambda_{\max }(\mathrm{nm})(\log \varepsilon)^{\mathrm{a}}$} & \multicolumn{1}{c}{$\mathrm{IR} \bar{v}\left(\mathrm{~cm}^{-1}\right)^{\mathrm{b}}$} \\
\hline$\left[\mathrm{Co}(\text { phen })_{3}\right]^{3+}$ & $349(4 \cdot 28), 303(4 \cdot 17), 275(4 \cdot 60)$ & $3659,1609,1524,1433,839,557$ \\
{$\left[\mathrm{Co}(\text { phen })_{2}(\right.$ phen- } & $303(4 \cdot 31), 274(4 \cdot 79), 259(4 \cdot 74)$, & $3647,1703,1524,1433,837,557$ \\
dione $]^{3+}$ & $220(5 \cdot 05)$ & \\
{$\left[\mathrm{Co}(\text { phen })_{2}(\mathrm{dppz})\right]^{3+}$} & $377(4 \cdot 23), 359(4 \cdot 29), 282(5 \cdot 11)$, & $3653,1608,1524,1433,858,557$ \\
& $223(5 \cdot 10)$ & \\
{$\left[\mathrm{Ni}(\text { phen })_{3}\right]^{2+}$} & $293(4 \cdot 57), 269(5 \cdot 05), 227(5 \cdot 11)$ & $3668,1626,1520,1427,835,557$ \\
{$\left[\mathrm{Ni}(\text { phen })_{2}(\right.$ phen- } & $358(4 \cdot 13), 325(4 \cdot 14), 273(5 \cdot 03)$, & $3652,1701,1520,1428,839,557$ \\
dione $)]^{2+}$ & $226(4 \cdot 92)$ & \\
{$\left[\mathrm{Ni}(\text { phen })_{2}(\text { dppz })\right]^{2+}$} & $376(4 \cdot 12), 358(4 \cdot 13), 325(4 \cdot 14)$, & $3646,1607,1585,1521,1431,839$ \\
& $273(5 \cdot 03), 223(4 \cdot 96)$ & \\
{$\left[\mathrm{Ru}(\text { phen })_{3}\right]^{2+}$} & $446(4 \cdot 28), 422(4 \cdot 25), 263(5 \cdot 07)$, & $3654,1622,1496,1428,840,557$ \\
& $223(4 \cdot 93)$ & \\
{$\left[\mathrm{Ru}(\text { phen })_{2}(\right.$ phen- } & $441(4 \cdot 29), 329(4 \cdot 51), 261(5 \cdot 11)$, & $3659,1701,1498,1429,838,558$ \\
dione $)]^{2+}$ & $225(4 \cdot 92)$ & \\
{$\left[\mathrm{Ru}(\text { phen })_{2}(\mathrm{dppz})\right]^{2+}$} & $443(4 \cdot 33), 369(4 \cdot 39), 360(4 \cdot 33)$, & $3651,1628,1491,1427,837,557$ \\
& $277(5 \cdot 12), 225(5 \cdot 02)$ & \\
\hline
\end{tabular}

${ }^{\mathrm{a}}$ Spectra were measured in $\mathrm{CH}_{3} \mathrm{CN}$. Error limits: $\lambda_{\max }, \pm 2 \mathrm{~nm} ; \log \varepsilon, \pm 10 \%$

${ }^{\mathrm{b}} \mathrm{Spectra}$ were measured as $\mathrm{KBr}$ pellets 
Table 2. ${ }^{1} \mathrm{H}$ NMR and magnetic susceptibility data ${ }^{\mathrm{a}}$.

\begin{tabular}{|c|c|c|}
\hline Complex & $\delta \mathrm{ppm}^{\mathrm{a}}$ & $\mu_{\mathrm{eff}}(\mathrm{BM})^{\mathrm{b}}$ \\
\hline$\left[\mathrm{Co}(\text { phen })_{3}\right]^{3+}$ & $9.19(d, 6 \mathrm{H}), 8.58(s, 6 \mathrm{H}), 7.98(d d, 6 \mathrm{H}), 7.68(d, 6 \mathrm{H})$ & \\
\hline$\left[\mathrm{Co}(\text { phen })_{2}(\text { phen-dione })\right]^{3+}$ & $9.17(d, 6 \mathrm{H}), 8.56(s, b r, 4 \mathrm{H}), 7.96(m, 6 \mathrm{H}), 7.66(d, 6 \mathrm{H})$ & \\
\hline$\left[\mathrm{Co}(\text { phen })_{2}(\mathrm{dppz})\right]^{3+}$ & $\begin{array}{l}9.95(d d, 2 \mathrm{H}), 9 \cdot 21(d, 2 \mathrm{H}), 8.18(d, 2 \mathrm{H}), 8.59(m, 8 \mathrm{H}), \\
8.32(d, 4 \mathrm{H}), 8.00(m, 4 \mathrm{H}), 7.68(d, 4 \mathrm{H})\end{array}$ & \\
\hline$\left[\mathrm{Ru}(\text { phen })_{3}\right]^{2+}$ & $8 \cdot 80(d d, 6 \mathrm{H}), 8 \cdot 39(s, 6 \mathrm{H}), 8.09(d d, 6 \mathrm{H}), 7 \cdot 76(d, 6 \mathrm{H})$ & \\
\hline$\left[\mathrm{Ru}(\text { phen })_{2}(\text { phen-dione })\right]^{2+}$ & $9 \cdot 26(d, 6 \mathrm{H}), 8 \cdot 71(s, b r, 4 \mathrm{H}), 8 \cdot 12(m, 6 \mathrm{H}), 7 \cdot 82(d, 6 \mathrm{H})$ & \\
\hline$\left[\operatorname{Ru}(\text { phen })_{2}(\mathrm{dppz})\right]^{2+}$ & $\begin{array}{l}9.73(d d, 2 \mathrm{H}), 8.82(d d, 2 \mathrm{H}), 8.79(d d, 2 \mathrm{H}), 8.60(d d, 2 \mathrm{H}), \\
8.50(d d, 2 \mathrm{H}), 8.48(m, 2 \mathrm{H}), 8.42(s, 4 \mathrm{H}), 8.39(d d, 2 \mathrm{H}), \\
8.18(m, 2 \mathrm{H}) 7.95(d d, 2 \mathrm{H}), 7.83(d d, 2 \mathrm{H}), 7.81(d d, 2 \mathrm{H})\end{array}$ & \\
\hline$\left[\mathrm{Ni}(\text { phen })_{3}\right]^{2+}$ & & 3.00 \\
\hline$\left[\mathrm{Ni}(\text { phen })_{2}(\text { phen-dione })\right]^{2+}$ & & $3 \cdot 11$ \\
\hline$\left[\mathrm{Ni}(\text { phen })_{2}(\mathrm{dppz})\right]^{2+}$ & & $3 \cdot 16$ \\
\hline
\end{tabular}

${ }^{\text {a }}$ Spectra were measured in DMSO- $d_{6} / \mathrm{CDCl}_{3}$ using TMS as an internal standard. Error limit: $\pm 0 \cdot 1 \mathrm{ppm}$

${ }^{\mathrm{b}}$ measured at $293 \pm 3 \mathrm{~K}$. Error limit: $\pm 10 \%$

on the other hand, showed additional MLCT charge transfer bands between 400-500 nm. This is illustrated in figure 2 which compares the UV/Visible spectra of $\left[\mathrm{Ru}(\mathrm{phen})_{2}(\mathrm{dppz})\right]^{2+}$ and $\left[\mathrm{Co}(\mathrm{phen})_{2}(\mathrm{dppz})\right]^{3+}$. Interestingly, each mixed ligand complex containing dppz absorbs at red-shifted wavelengths compared to the complexes containing phen-dione. While none of the $\mathrm{Co}$ (III) and Ni(II) complexes studied here were found to be fluorescent, each $\mathrm{Ru}(\mathrm{II})$ complex showed intense emission when excited into the MLCT band in $\mathrm{CH}_{3} \mathrm{CN}$. The emission quantum yield values $(\phi)$ of these complexes vary as $\left[\mathrm{Ru}(\text { phen })_{3}\right]^{2+}(0 \cdot 028)>\left[\mathrm{Ru}(\text { phen })_{2}(\mathrm{dppz})\right]^{2+}(0 \cdot 008)>\left[\mathrm{Ru}(\text { phen })_{2}(\text { phen-dione })\right]^{2+}$ $(0 \cdot 002)$.

Redox potentials of the ligands and the complexes, as obtained by the cyclic voltammetric method are summarized in table 3 . Wave analysis suggested that most of the voltammetric peaks represent diffusion controlled (ip vs $v^{1 / 2}=$ constant where ip is the peak current and $v$ is the scan rate), reversible $\left(i p_{a} / i p_{C}=0 \cdot 9-1.0\right.$ where $i p_{a}$ and $i p_{C}$ refer to anodic and cathodic peak potentials, respectively), one-electron transfer $\left(\Delta E_{p}=60\right.$ $70 \mathrm{mV}$ where $E_{p}$ is the peak potential) reactions, while the others are either quasireversible $\left(i p_{a} / i p_{C}=0.7-0.9\right.$ and $\left.\Delta E_{p}=80-200 \mathrm{mV}\right)$ or totally irreversible, as indicated in table 3. The peak assignments to the metal or the ligand based redox reactions are based on the reported electrochemical data of $\left[\mathrm{M}(\mathrm{phen})_{3}\right]^{2+}$ and $\left[\mathrm{M}(\mathrm{phen})_{2}(\mathrm{LL})\right]^{\mathrm{n}+}$ systems ${ }^{11,16,27,33}$. A comparison of the reduction potential data of free and metal-bound dppz and phen-dione in the mixed-ligand complexes containing these $\pi$-acceptor ligands suggests that the potential displacement between the free and the coordinated species varies between 0.03 and $0.35 \mathrm{~V}$. It is possible that the electronic coupling between these ligands and the metal ions is weak in their complexes. On the other hand, the potential displacement between the free and coordinated phen is $>1 \mathrm{~V}$ for the series of complexes investigated in this study. Finally, the redox wave corresponding to the $\mathrm{Co}^{\text {III/III }}$ couple for each $\mathrm{Co}$ (III) complex investigated here was found to be reversible and appear at potentials as low as $0 \cdot 37-0 \cdot 40 \mathrm{~V}$ in $\mathrm{CH}_{3} \mathrm{CN}, 0 \cdot 1 \mathrm{M}$ TBAP. 
Table 3. Redox potential data in $\mathrm{CH}_{3} \mathrm{CN}, 0 \cdot 1 \mathrm{M} \mathrm{TBAPF}_{6}{ }^{\mathrm{a}}$.

\begin{tabular}{lll}
\hline Comlex & Metal & \multicolumn{1}{c}{ Ligand } \\
\hline Phen & & $-2 \cdot 14^{*}$ \\
Phen-dione & & $-0 \cdot 45,-1 \cdot 08$ \\
dppz & $0 \cdot 38$ & $-1 \cdot 22,-1 \cdot 74^{*}$ \\
{$\left[\mathrm{Co}(\text { phen })_{3}\right]^{3+}$} & $0 \cdot 37$ & $-0 \cdot 98,-1 \cdot 67^{*}$ \\
{$\left[\mathrm{Co}(\text { phen })_{2}(\text { phen-dione })\right]^{3+}$} & $0 \cdot 40$ & $-0 \cdot 42^{*},-0 \cdot 90^{*}$ \\
{$\left[\mathrm{Co}(\text { phen })_{2}(\mathrm{dppz})\right]^{3+}$} & & $-0 \cdot 95,-1 \cdot 17,-1 \cdot 83^{*}$ \\
{$\left[\mathrm{Ni}(\text { phen })_{3}\right]^{2+}$} & & $-1 \cdot 32,-2 \cdot 02^{*}$ \\
{$\left[\mathrm{Ni}(\text { phen })_{2}(\text { phen-dione })\right]^{2+}$} & & $-0 \cdot 17,-0 \cdot 89$ \\
{$\left[\mathrm{Ni}(\text { phen })_{2}(\mathrm{dppz})\right]^{2+}$} & $1 \cdot 26$ & $-0 \cdot 99,-1 \cdot 32^{*}$ \\
{$\left[\mathrm{Ru}(\text { phen })_{3}\right]^{2+}$} & $1 \cdot 33$ & $-1 \cdot 28,-1 \cdot 44,-1 \cdot 71^{*}$ \\
{$\left[\mathrm{Ru}(\text { phen })_{2}(\mathrm{dppz})\right]^{2+}$} & & $-0 \cdot 87,-1 \cdot 29,-1 \cdot 53$ \\
\hline
\end{tabular}

${ }^{a}$ Error limit: $\pm 0.03 \mathrm{~V}$

*Quasi-reversible/irreversible (electrochemical behaviour of $\left[\mathrm{Ru}(\mathrm{phen})_{2}\right.$ (phendione) $]^{2+}$ was found to be ill-defined)

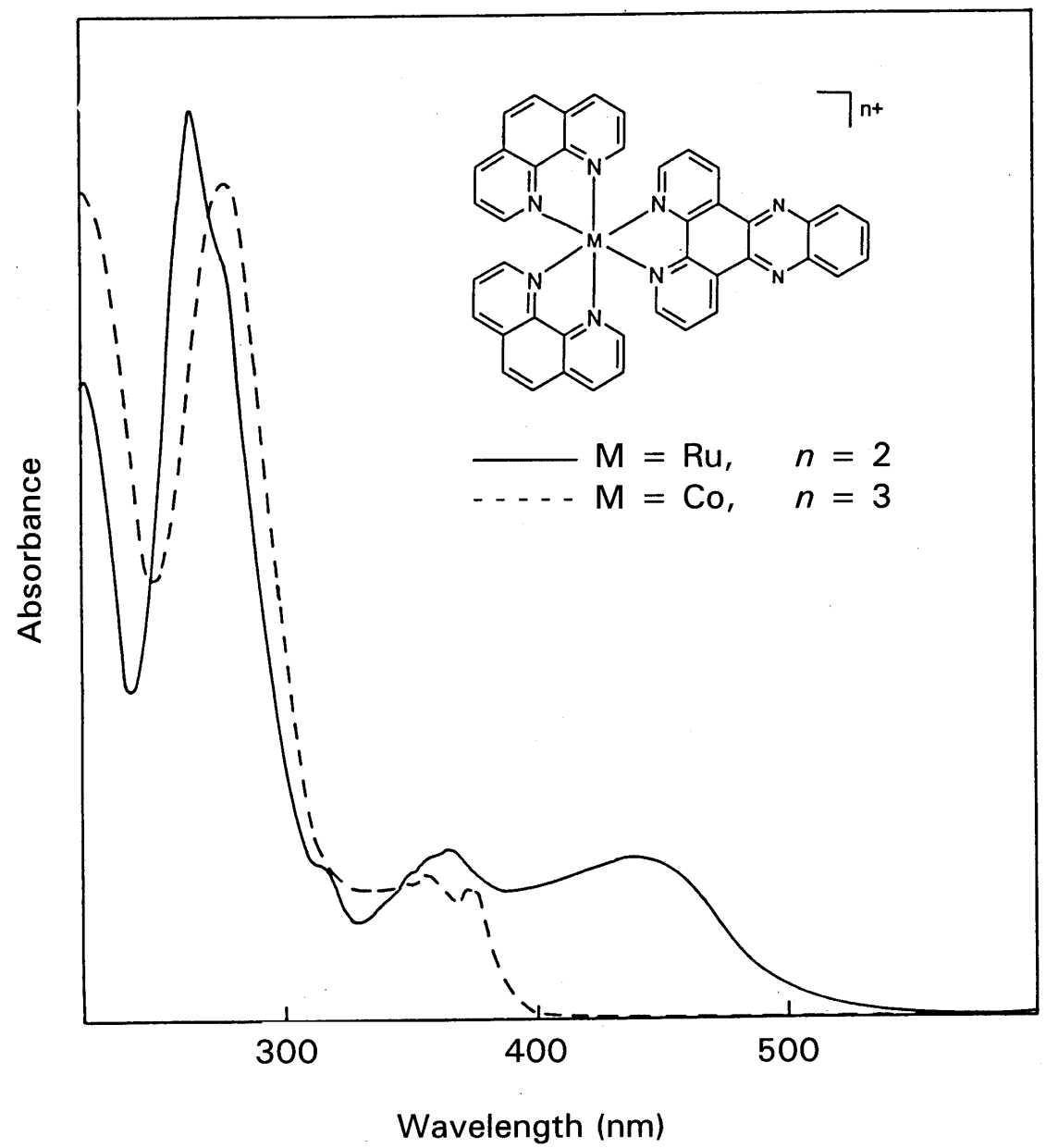

Figure 2. UV/Visible spectra of $\left[\mathrm{Co}(\mathrm{phen})_{2}(\mathrm{dppz})\right]^{3+}$ and $\left[\mathrm{Ru}(\mathrm{phen})_{2}(\mathrm{dppz})\right]^{2+}$ in $\mathrm{CH}_{3} \mathrm{CN}$. 
Thus, the UV/Visible data suggest that DNA interaction by all the dppz-based complexes, having absorption peaks at wavelengths $>300 \mathrm{~nm}$ (up to which DNA itself absorbs), can be monitored by the absorption titration method. In addition, while the interaction of each $\mathrm{Ru}$ (II) complex with DNA can be specifically probed by emission titration, that by the $\mathrm{Co}(\mathrm{III})$ complexes can be probed by electrochemical methods.

\subsection{DNA binding studies}

Addition of increasing amounts of CT-DNA resulted in a decrease of absorbance for each investigated dppz complex and also that of $\left[R u(p h e n)_{2}(\text { phen-dione })\right]^{2+}$ and $\left[R u(p h e n)_{3}\right]^{2+}$. Representative spectra illustrating this hypochromicity and the presence of isosbestic points observed for the interaction of $\left[\mathrm{Ru}(\mathrm{phen})_{2}\right.$ (phen-dione $\left.)\right]^{2+}$ with CT-DNA are given in figure 3. Change in absorbance at the peak maximum of the most red-shifted band of each complex with increasing concentration of DNA has been monitored for an evaluation of the intrinsic binding constant using (1) (see figure 3 inset, for the plot using (1)); the binding constants thus obtained are given in table 4. As reported earlier, dppz complexes of $\mathrm{Co}(\mathrm{III}), \mathrm{Ni}(\mathrm{II})$ and $\mathrm{Ru}(\mathrm{II})$ are found to be avid binders of CT DNA with the

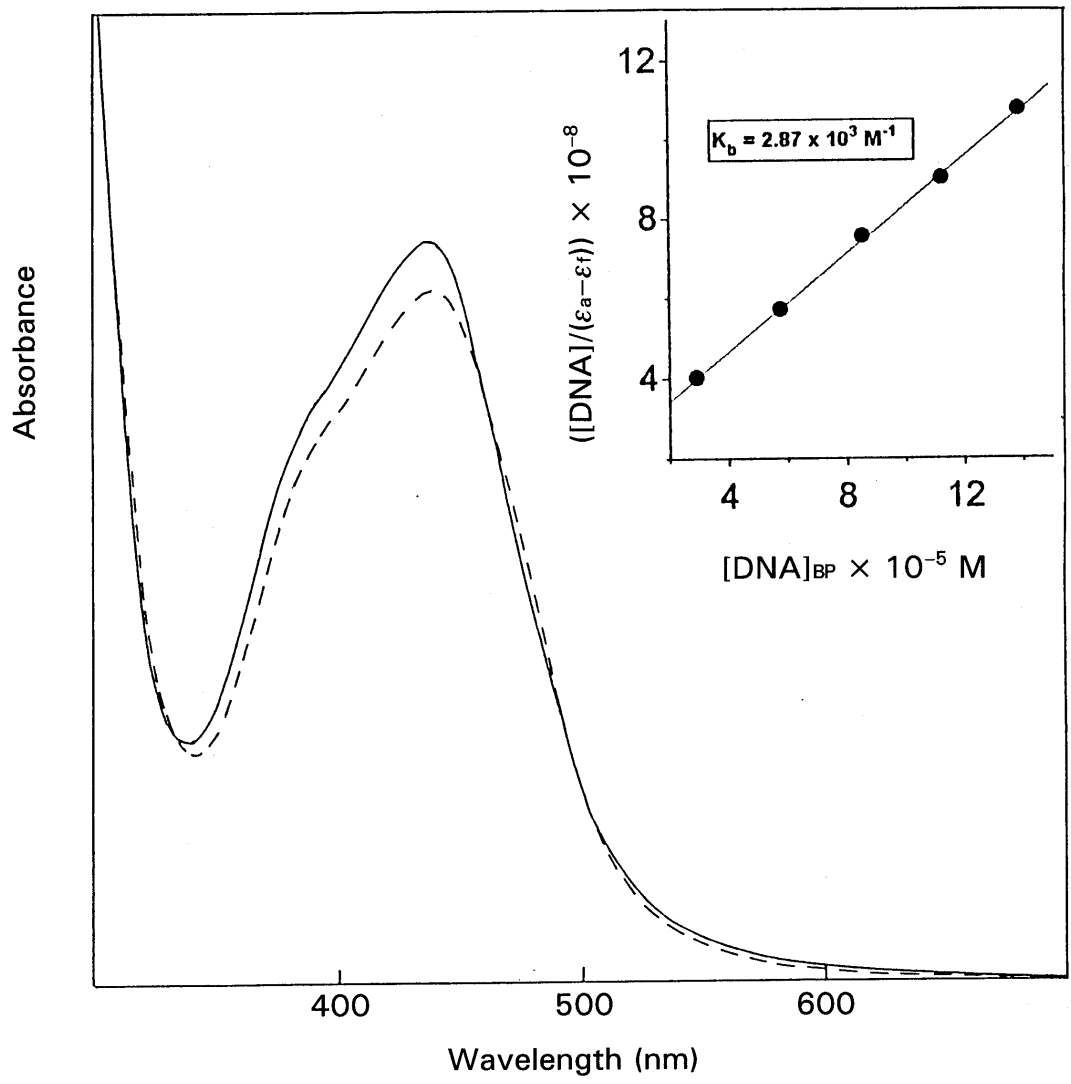

Figure 3. UV/Visible spectra of $\left[\mathrm{Ru}(\text { phen })_{2}\right.$ (phen-dione $\left.)\right]^{2+}(10 \mu \mathrm{M})$ with (- - - - ) and without (-) CT-DNA $(100 \mu \mathrm{M}$ in base-pairs) in buffer A. Inset: Plot of $[\mathrm{DNA}] /\left(\varepsilon_{a}-\varepsilon_{f}\right)$ vs $[\mathrm{DNA}]$ for this interaction. 
Table 4. Results of absorption titration $\left(K_{b}\right)$ and thermal denaturation $\left(T_{m}\right)$ studies.

\begin{tabular}{lccc}
\hline Complex & $K_{b}, \mathrm{M}^{-1 \mathrm{a}}$ & $T_{m}{ }^{\circ} \mathrm{C}^{\mathrm{b}}$ & $\sigma_{T}{ }^{\circ \mathrm{c}}$ \\
\hline$\left[\mathrm{Co}(\text { phen })_{3}\right]^{3+}$ & - & 66 & 26 \\
{$\left[\mathrm{Co}(\text { phen })_{2}(\text { phen-dione })\right]^{3+}$} & - & 65 & 24 \\
{$\left[\mathrm{Co}(\text { phen })_{2}(\text { dppz })\right]^{3+}$} & $5 \cdot 05 \times 10^{5}$ & 68 & 25 \\
{$\left[\mathrm{Ni}(\text { phen })_{3}\right]^{2+}$} & - & 64 & 26 \\
{$\left[\mathrm{Ni}(\text { phen })_{2}(\text { phen-dione })\right]^{2+}$} & - & 64 & 24 \\
{$\left[\mathrm{Ni}(\text { phen })_{2}(\right.$ dppz $\left.)\right]$} & $1 \cdot 51 \times 10^{5}$ & 66 & 27 \\
{$\left[\mathrm{Ru}(\text { phen })_{3}\right]^{2+}$} & $7 \cdot 88 \times 10^{3}$ & 66 & 27 \\
{$\left[\mathrm{Ru}(\text { phen })_{2}(\text { phen-dione })\right]^{2+}$} & $2 \cdot 87 \times 10^{3}$ & 66 & 25 \\
{$\left[\mathrm{Ru}(\text { phen })_{2}(\text { dppz })\right]^{2+}$} & $>10^{6}$ & 67 & 26 \\
\hline
\end{tabular}

${ }^{a}$ Error limit: $\pm 10 \%$

${ }^{\mathrm{b}}[$ DNA nucleotide phosphate $] /[\mathrm{drug}]=25$; error limit $\pm 1^{\circ} \mathrm{C}$

${ }^{c}$ Error limit: $\pm 2^{\circ}$

binding constants being in the range of $1.5 \times 10^{4}->10^{6} \mathrm{M}^{-111,37-39}$. On the other hand, both $\left[\mathrm{Ru}(\mathrm{phen})_{3}\right]^{2+}$ and $\left[\mathrm{Ru}(\mathrm{phen})_{2}(\text { phen-dione })\right]^{2+}$ bind less efficiently; the derived $K_{b}$ values in these cases are $\approx$ more than two orders of magnitude less than that for the corresponding dppz complex. In fact, $K_{b}$ values as derived from the absorption titration method for these $\mathrm{Ru}(\mathrm{II})$ complexes vary as $\left[\mathrm{Ru}(\mathrm{phen})_{2}(\mathrm{dppz})\right]^{2+}>\left[\mathrm{Ru}(\mathrm{phen})_{3}\right]^{2+}>$ $\left[\mathrm{Ru}(\text { phen })_{2} \text { (phen-dione) }\right]^{2+}$.

A similar effect was noticed during the fluorescence titration experiments using these emissive $\mathrm{Ru}$ (II) complexes in the presence of DNA. Luminescence due to each $\mathrm{Ru}$ (II) complex was seen to increase steadily with increasing addition of CT-DNA, figure 4. As seen, the maximum enhancement factors (at saturation) noticed for $\left[\mathrm{Ru}(\mathrm{phen})_{2}(\mathrm{dppz})\right]^{2+}$, $\left[\mathrm{Ru}(\text { phen })_{3}\right]^{2+}$ and $\left[\mathrm{Ru}(\text { phen })_{2}(\text { phen-dione })\right]^{2+}$ are $>10^{4}, 2$ and 1.8 respectively. It is pertinent to mention here that the $10^{4}$-fold emission enhancement observed for $\left[\mathrm{Ru}(\mathrm{phen})_{2}(\mathrm{dppz})\right]^{2+}$ has been ascribed earlier to protection of the imine nitrogens of the fused phenazine subunit on dppz from attack by water and consequent decrease in the non-radiative processes upon intercalation with $\mathrm{DNA}^{37,38,41-44}$. Such a process is obviously lacking in $\left[\operatorname{Ru}(\text { phen })_{3}\right]^{2+}$ and $\left[\operatorname{Ru}(\text { phen })_{2}(\text { phen-dione })\right]^{2+}$, both of which do not possess the fused phenazine subunit in their architecture.

Owing to the lack of an absorption band above $\approx 300 \mathrm{~nm}$, a wavelength up to which DNA itself absorbs, the binding affinities of the phen and phen-dione complexes of $\mathrm{Co}$ (III) and Ni(II) could not be investigated by the absorption titration method. Nor was it possible to monitor the binding of these complexes by the fluorescence titration method, as they were all found to be essentially non-emissive both in the absence and presence of DNA. However, application of the differential-pulse voltammetric method permitted an estimate of DNA binding affinities of the Co(III) complexes as described below.

Differential-pulse voltammetric experiments carried out in buffer B for $\left[\mathrm{Co}(\mathrm{phen})_{3}\right]^{3+}$, $\left[\mathrm{Co}(\text { phen })_{2}(\text { phen-dione })\right]^{3+}$ and $\left[\mathrm{Co}(\text { phen })_{2}(\mathrm{dppz})\right]^{3+}$ both in the presence and absence of CT DNA have revealed that there is a decrease in the peak-current due to $\mathrm{Co} / \mathrm{III} / \mathrm{Co}^{\mathrm{II}}$ redox couple in the presence of DNA. The decrease in the current value is more pronounced for the dppz containing complex compared to that for the phen and phen-dione complexes. The current values for $\left[\mathrm{Co}(\mathrm{phen})_{2}(\mathrm{dppz})\right]^{3+},\left[\mathrm{Co}(\text { phen })_{3}\right]^{3+}$ and $\left[\mathrm{Co}(\text { phen })_{2}(\text { phen-dione })\right]^{3+}$ 


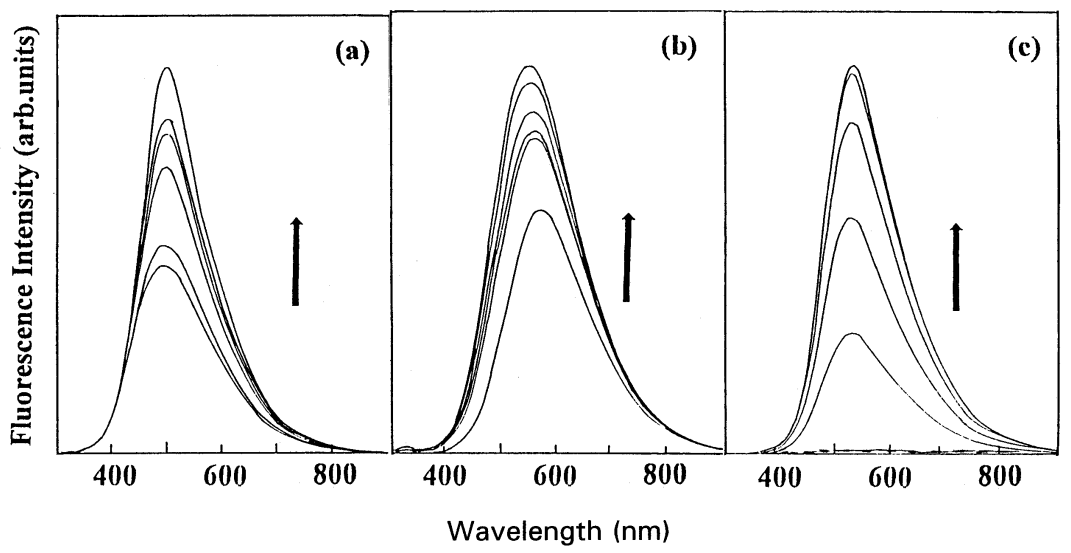

Figure 4. Emission enhancement observed for the three $\mathrm{Ru}(\mathrm{II})$ complexes $(10 \mu \mathrm{M}$, buffer A) with increasing concentration of CT-DNA. (a) $\left[\mathrm{Ru}(\text { phen })_{3}\right]^{2+}$, (b) $\left[\mathrm{Ru}(\mathrm{phen})_{2}(\text { phen-dione })\right]^{2+}$ and (c) $\left[\mathrm{Ru}(\mathrm{phen})_{2}(\mathrm{dppz})\right]^{2+}$. Maximum DNA concentrations added (nucleotide phosphates) are 800,800 and $100 \mu \mathrm{M}$ for (a), (b) and (c), respectively.

at a $[\mathrm{DNA}] /[\mathrm{Co}]=40$ were respectively 30,50 and $80 \%$ of the corresponding values in the absence of DNA. This trend is consistent with that noticed above for the ruthenium(II) complexes during the absorption and fluorescence titration experiments.

A comparison of the available intrinsic binding characteristics by these complexes thus appears to suggest that, in general, DNA binding by the dppz containing complexes is far too strong than that by the complexes containing phen or phen-dione ligands, with the latter species being the weakest binding agents among all the systems investigated in this study. This supposition is further substantiated by the results of thermal denaturation, viscometric titration and agarose gel electrophoresis experiments, the results of which are described below.

Thermal denaturation curves for DNA in the presence and absence of a representative complex are given in figure 5 and the relevant data for all the complexes investigated in this study are summarized in table 4. It is clear from this figure and the data given in table 4 that while the dppz containing complexes shift the $T_{m}$ values by up to $8^{\circ}$, the $T_{m}$ values for DNA samples containing the tris-phen and bis(phen)(phen-dione) complexes, in general, are not so high compared to that of the pure DNA sample $\left(60 \pm 1^{\circ} \mathrm{C}\right)^{30}$.

Intercalation of a ligand to DNA is known to cause a significant increase in the viscosity of a DNA solution due to an increase in the separation of the base pairs at the intercalation site and, hence, an increase in the overall DNA molecular length. In contrast, a ligand that binds in the DNA grooves causes either a less pronounced change (positive or negative) or no change in the viscosity of a DNA solution ${ }^{45,46}$. The effect of each investigated complex on the viscosity of CT-DNA solution was studied in order to assess the binding mode and strength of these complexes with DNA. Representative plots of $\eta / \eta_{\mathrm{o}}$ vs $[\mathrm{drug}] /[\mathrm{DNA}]$ are shown in figure 6 for the cobalt(III) complexes. As seen in this figure, while $\left[\mathrm{Co}(\mathrm{phen})_{3}\right]^{3+}$ does not affect the DNA viscosity as previously reported for this tris-phen complex ${ }^{32}$, positive and negative changes of viscosity with increasing addition of the complex are seen for $\left[\mathrm{Co}(\mathrm{phen})_{2}(\mathrm{dppz})\right]^{3+}$ and $\left[\mathrm{Co}(\mathrm{phen})_{2}(\text { phen-dione })\right]^{3+}$ 


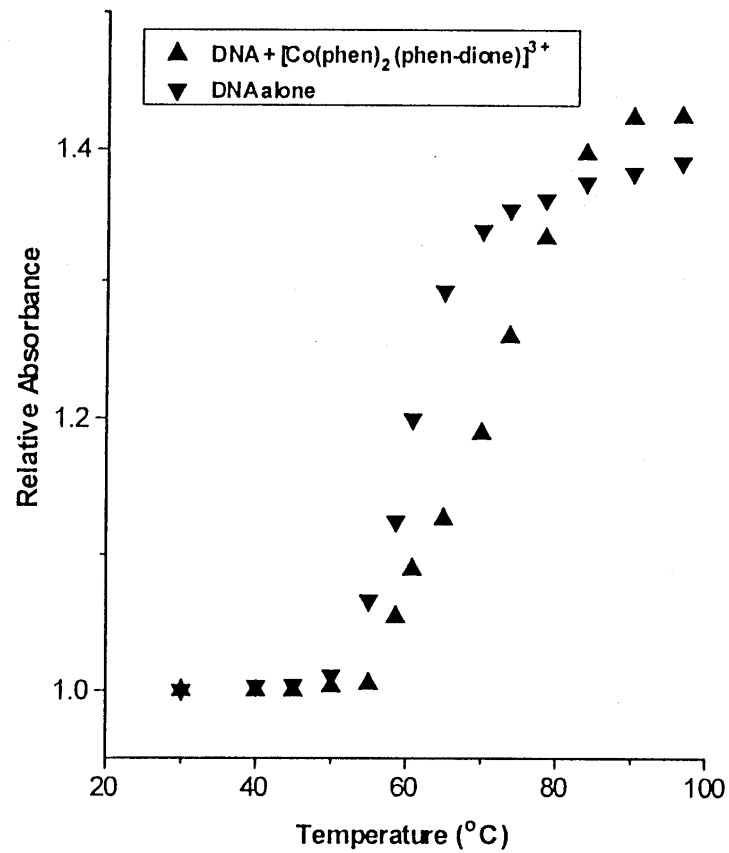

Figure 5. Melting curves (buffer B) for DNA alone ${ }_{t}$ ) and DNA $+\left[\mathrm{Co}(\text { phen })_{2}\right.$ (phendione $)]^{3+}\left({ }_{s}\right)$. [DNA $]=160 \mu \mathrm{M}$. [Drug $]=8 \mu \mathrm{M}$.

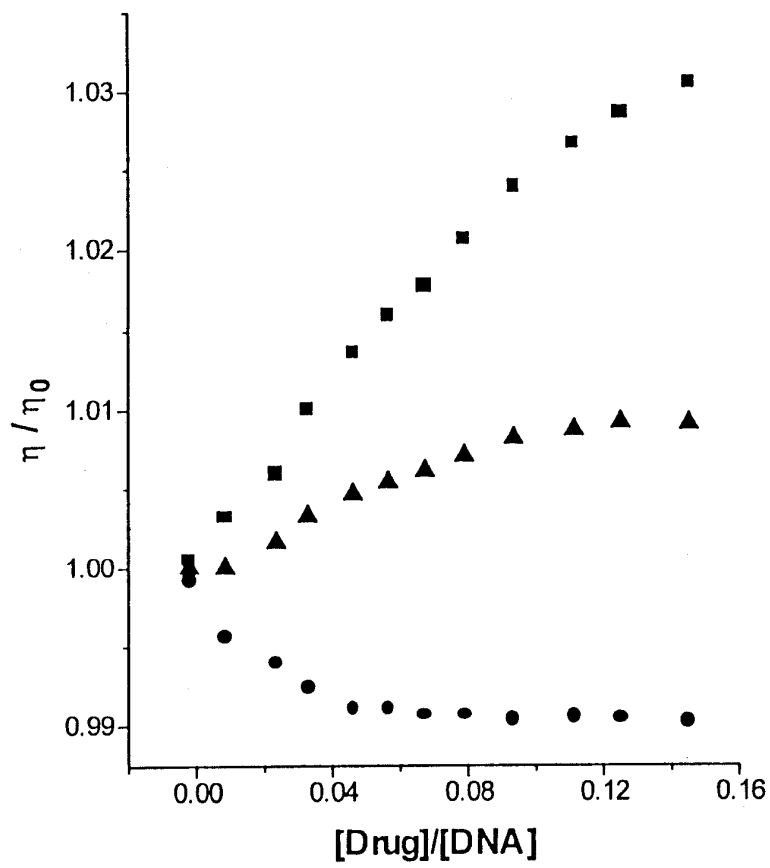

Figure 6. Plots of $\eta / \eta_{\text {o }}$ vs $\left[\right.$ drug]/[DNA] (buffer B) for $\left[\mathrm{Co}(\text { phen })_{2} \text { (phen-dione) }\right]^{3+}$ $(\bullet),\left[\mathrm{Co}(\text { phen })_{3}\right]^{2+}(s)$ and $\left[\mathrm{Co}(\text { phen })_{2}(\mathrm{dppz})\right]^{2+}(\mathbf{\square})$. 
suggesting an intercalative mode of binding by the dppz-complex ${ }^{31,32}$. A similar trend was noticed for the $\mathrm{Ni}(\mathrm{II})$ and $\mathrm{Ru}(\mathrm{II})$ analogues.

It has been suggested in the case of tris-phen complexes of various metal ions, that only one among the three phen ligands is involved in the intercalative mode of binding with DNA ${ }^{47}$. On the other hand, results of various spectroscopic and biochemical studies have shown that the mixed-ligand complexes $\left[\operatorname{Ru}(\mathrm{bpy})_{2}(\mathrm{dppz})\right]^{2+},\left[\mathrm{Ru}(\mathrm{phen})_{2}(\mathrm{dppz})\right]^{2+}$, $\left[\mathrm{Co}(\text { phen })_{2}(\mathrm{dppz})\right]^{3+}, \quad\left[\mathrm{Ni}(\mathrm{phen})_{2}(\mathrm{dppz})\right]^{2+}$ and $\left[\mathrm{Ru}(\mathrm{O})(\mathrm{dppz})(\mathrm{tpy}]^{2+}(\mathrm{tpy}=\right.$ terpyridine $)$ strongly bind to DNA and that it is the dppz ligand on them that binds with DNA $^{11,37,38,41-44,48}$. In particular, bathochromic shifts and hypso-chromism in their UV/Visible spectrum, increased values of both the DNA melting temperature and the curve width in the thermal denaturation experiments and enhanced viscosity changes in the presence of DNA have all been argued in favour of an intercalative mode of binding by the coordinated dppz. Several factors which include the shape and hydrophobicity of the complex as well as extension of planarity and the presence of additional donor functionalities on the dppz ligand have been cited to be of importance in rendering these complexes to be such strong intercalative, major groove binding agents. It should be noted here that each dppz-based complex investigated in the present study also exhibited spectral, electrochemical and viscosity changes in the presence of DNA that are analogous to those exhibited by the complexes mentioned above. On the other hand, less pronounced spectral and viscosity changes have been observed for the phen and phendione complexes in the presence of DNA. Clearly, the intercalative ability of dppz is far too superior to that of phen and phen-dione.

Taking the above facts into consideration, we propose that only one among the three ligands on each complex is involved with the intercalative binding with the CT DNA and that the intercalative ability of the ligands varies as dppz > phen > phen-dione in this series of complexes. The fact that coordinated dppz and phen bind to DNA is wellknown. However, to our knowledge, DNA binding abilities of the phen-dione complexes have never been tested. The results obtained in this study indicate that coordinated phendione is a poor intercalator unlike dppz and phen. Indeed, the viscosity and thermal denaturation parameters of DNA have been noticed to be relatively insensitive to the presence of tris(phen-dione) complexes $\left.[\mathrm{M} \text { (phen-dione })_{3}\right]^{\mathrm{n}+}(\mathrm{M}=\mathrm{Co}$ (III) or $\mathrm{Ni}$ (II) and $n=2$ or 3) (data not shown). Notwithstanding this latter observation, it is unclear at present whether it is phen-dione or phen that is involved in the binding of $\left[\mathrm{M}(\mathrm{phen})_{2}(\text { phen-dione })\right]^{\mathrm{n}+}$ systems investigated in this study. Nonetheless, it is interesting to note that extending the $\pi$-conjugation in the phenanthroline family of ligands, as is done in the case of dppz, results in strong intercalative agents. On the other hand, substitution of the hydrogen-bonding acceptors onto the phenanthroline ligands, such as for example the carbonyl groups of phen-dione, does not seem to provide any additional stabilization for binding by the ensuing complexes with DNA. Indeed, whereas complexes of modified phen ligands with fused aromatic groups are known to strongly bind to $\mathrm{DNA}^{49,50}\left[\mathrm{Ru}(\mathrm{phen})_{2}(\text { flone })\right]^{2+}$, where flone is 4,5-diazafluorene-9-one-a potentially hydrogen-bonding ligand - shows poor affinity towards DNA as is the case with the phendione complexes investigated in this study ${ }^{50}$.

\subsection{Photocleavage of DNA}

DNA photocleavage by the cobalt(III) complexes has been investigated in detail in this study. Control experiments have suggested that untreated DNA does not show any 
cleavage in the dark and even upon irradiation by light. Control experiments have also suggested that phen, phen-dione and dppz (free-ligands, dissolved in 10\% DMF) are not detectably active under the dark and light irradiated conditions. DNA nicking was not observed for pBR 322 treated with any of the complexes investigated in this study in the dark experiments. On the other hand, irradiation of DNA in the presence of the three $\mathrm{Co}$ (III) complexes caused the generation of relaxed circular DNA $\left(\lambda_{\mathrm{exc}}=313 \pm 5 \mathrm{~nm}\right)$ with the nicking efficiency roughly following the order $\left[\mathrm{Co}(\mathrm{phen})_{2}(\mathrm{dppz})\right]^{3+}(1.0)>$ $\left[\mathrm{Co}(\text { phen })_{3}\right]^{3+}(0 \cdot 8)>\left[\mathrm{Co}(\text { phen })_{2}(\text { phen-dione })\right]^{3+}(0 \cdot 7)$. It should be noted that, at this wavelength these complexes show more equal absorbance (log $\varepsilon$ values at $313 \mathrm{~nm}$ are $4.23,4.16$ and $4 \cdot 10$ for the three complexes in that order) than at $350 \mathrm{~nm}$ where only $\left[\mathrm{Co}(\mathrm{phen})_{2}(\mathrm{dppz})\right]^{3+}$ is capable of absorbing light. Accordingly, when the $\lambda_{\mathrm{exc}}$ was changed to $350 \pm 5 \mathrm{~nm}$ from $313 \pm 5 \mathrm{~nm}$, only $\left[\mathrm{Co}(\mathrm{phen})_{2}(\mathrm{dppz})\right]^{3+}$ was found to effect the DNA cleavage. These observations highlight the importance of dppz in this class of cobalt complexes and suggest that it is essential to further probe the interaction of $\left[\mathrm{Co}(\text { phen })_{2}(\mathrm{dppz})\right]^{3+}$ with pBR 322 DNA in order to gain insight into the mechanism of the photocleavage reaction.

Irradiation of pBR 322 samples containing $\left[\mathrm{Co}(\mathrm{phen})_{2}(\mathrm{dppz})\right]^{3+}$ was carried out in the presence of various 'inhibitors' (figure 7). Neither $\mathrm{N}_{2}$ (used to purge $\mathrm{O}_{2}$ from the sample, lane 3) nor DABCO (lane 5) - $\mathrm{a}^{1} \mathrm{O}_{2}$ 'quencher' and $\mathrm{SOD}-\mathrm{a} \mathrm{O}_{2}^{-}$' 'scavenger' (lane 6) inhibit the photocleavage by the complex. On the other hand, DMSO (and also mannitol or ethanol, data not shown) which scavenges $\mathrm{OH}^{*}$ radical seems to inhibit the photocleavage (lane 4). Further support for the generation of $\mathrm{OH}^{\bullet}$ upon photolysis of the complex comes from the spin trapping experiments. In the presence of PBN as the spin trap, irradiated solutions of $\left[\mathrm{Co}(\mathrm{phen})_{2}(\mathrm{dppz})\right]^{3+}$ in deaerated aqueous buffer (phosphate buffer $p \mathrm{H}=7.0$ ) indeed exhibited an ESR spectrum consisting of three doublets $\left(g=2 \cdot 006, a^{\mathrm{N}}=15 \cdot 2 \mathrm{G}\right.$ and $\left.a^{\mathrm{H}}=2 \cdot 8 \mathrm{G}\right)$ typical of the $\mathrm{OH}$ spin adduct of $\mathrm{PBN}^{51}$. In addition, a complex ESR spectrum was obtained when irradiation of the complex was carried out in deaerated acetonitrile solution containing $\approx 1 \%$ water, figure 8 . As seen in this figure, apart from a major three-line pattern due to $\mathrm{PBN}-\mathrm{OH}$ spin adduct, the

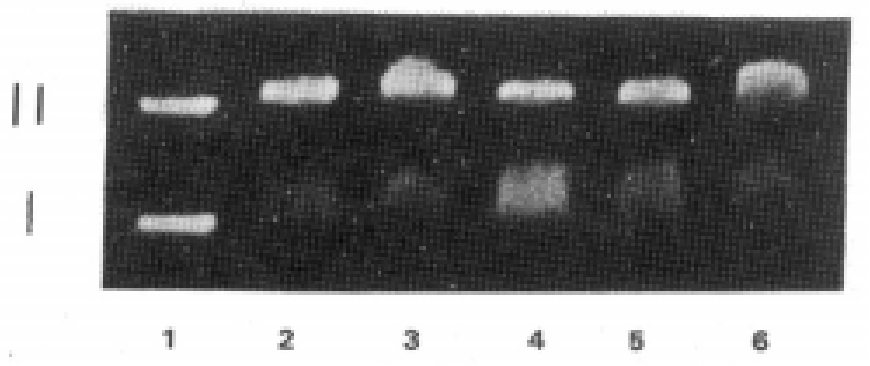

Figure 7. Photograph showing effects of 'inhibitors' on the light-induced nuclease activity of $\left[\mathrm{Co}(\text { phen })_{2}(\mathrm{dppz})\right]^{3+}$ : Lane 1: Untreated pBR $322(100 \mu \mathrm{M}$ nucleotide phosphate $)^{41}$, Lane $2:$ pBR $322+\left[\mathrm{Co}(\mathrm{phen})_{2}(\mathrm{dppz})\right]^{3+}(100 \mu \mathrm{M}){ }^{65}$, Lanes 3-6: pBR $322+\left[\mathrm{Co}(\text { phen })_{2}(\mathrm{dppz})\right]^{3+}$ in the presence of $\mathrm{N}_{2}{ }^{70}$, DMSO $(0 \cdot 2 \mathrm{M})^{45}$, DABCO $(10 \mathrm{mM})^{62}$ and SOD $(20 \mu \mathrm{g} / \mathrm{ml})^{72}$, respectively. Irradiation time $=45 \mathrm{~min}$ in each case and $\lambda_{\text {exc }}=350 \pm 5 \mathrm{~nm}$. Numbers given in square-parentheses refer to percentages of form II DNA. 


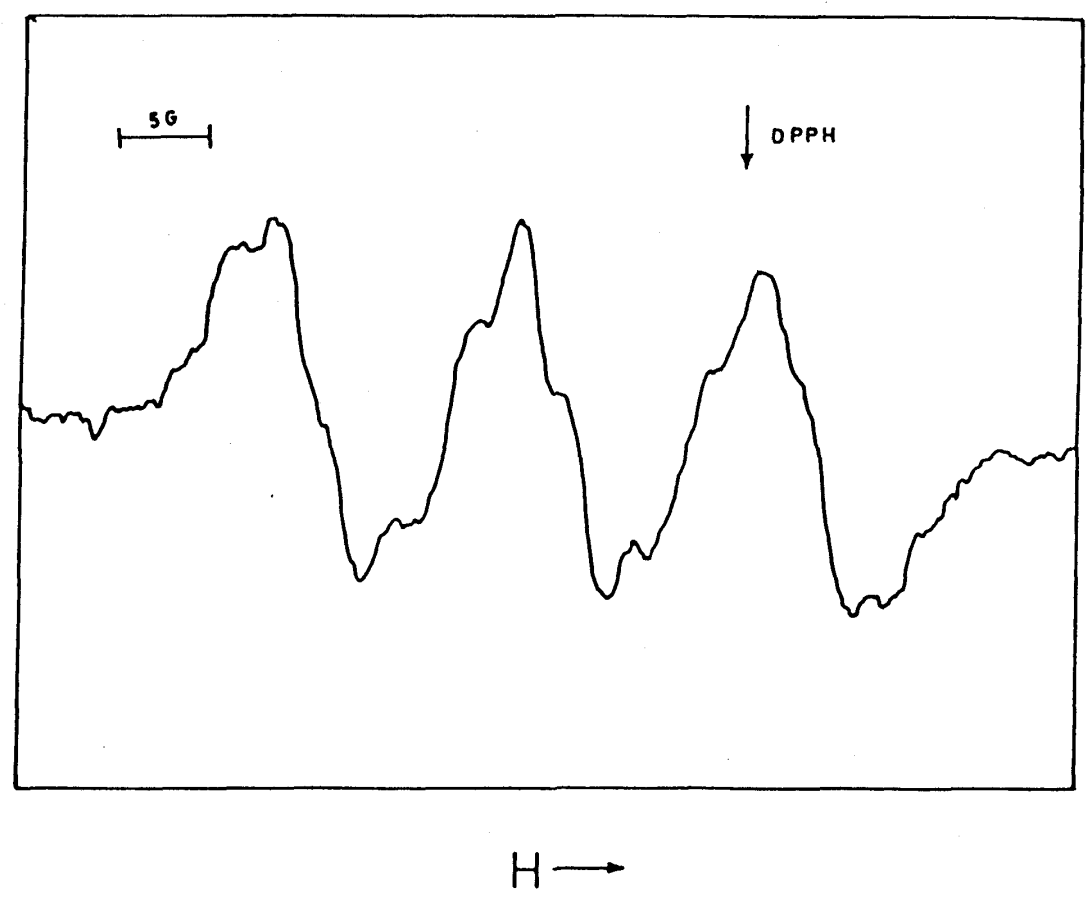

Figure 8. ESR spectrum obtained when $1 \mathrm{mM}$ of $\left[\mathrm{Co}(\mathrm{phen})_{2}(\mathrm{dppz})\right]^{3+}$ was irradiated $\left(\lambda_{\mathrm{exc}}=350 \pm 5 \mathrm{~nm}\right)$ in acetonitrile solution containing $1 \%$ water.

spectrum also shows several splittings which we ascribe to the resonances of a ligand $\mathrm{C} / \mathrm{N}$-based radical ${ }^{52}$. Thus, it is possible that irradiation facilitates a process of ligand reduction in $\left[\mathrm{Co}(\mathrm{phen})_{2}(\mathrm{dppz})\right]^{3+}$, a process that leads to the production of DNA-cleaving $\mathrm{OH}^{\cdot}$ radical via the reaction of a $\mathrm{C} / \mathrm{N}$-based radical intermediate with the buffered water. Notwithstanding these evidences in favour of the presence of hydroxyl radicals, we believe that the participation of other reactive species cannot be altogether ruled out in the observed photocleavage reaction.

The three ruthenium(II) complexes also exhibited light induced nuclease activity when irradiated into their respective MLCT bands $\left(\lambda_{\text {exc }}=450 \pm 5 \mathrm{~nm}\right)$. Detailed studies on the DNA photocleavage by $\left[\mathrm{Ru}(\mathrm{phen})_{3}\right]^{2+}$ have been carried out previously and it has been reported that $\mathrm{O}_{2}^{-}$and ${ }^{1} \mathrm{O}_{2}$ are the two important species responsible for the DNA damage ${ }^{53,30}$. We expect that photocleavage reactions of $\left[\mathrm{Ru}(\mathrm{phen})_{2}(\mathrm{dppz})\right]^{2+}$ and $\left[\mathrm{Ru}(\mathrm{phen})_{2}(\text { phen-dione })\right]^{2+}$ also involve these cytotoxic species. In addition, $\left[\mathrm{Ru}(\mathrm{phen})_{2}(\mathrm{dppz})\right]^{2+}$ has recently been reported to induce oxidative damage to DNA by rapidly oxidizing the guanine moieties upon irradiation ${ }^{54}$. Finally, none of the $\mathrm{d}^{8}$ nickel(II) systems showed light-induced nuclease activity under our experimental conditions, probably because of the paramagnetic nature of these complexes that, in principle, would render the excited states of these molecules ineffective.

In summary, the results described in this study demonstrate that substitution by different ligands or metal ions in metallo-intercalators of the type $\left[\mathrm{M}(\mathrm{phen})_{2} \mathrm{LL}\right]^{\mathrm{n}+}$ can bring about subtle modulation in the properties of this class of mixed-ligand complexes and, consequently, in their interactions with DNA. 


\section{Acknowledgements}

We are grateful to the Department of Science and Technology, New Delhi for financial support for this work. In addition, we thank the Central Drug Research Institute, Lucknow for recording the mass spectra. SA acknowledges a research fellowship from the Jawaharlal Nehru Centre for Advanced Scientific Research, Bangalore. DE is grateful to the Tamil Nadu State Council for Science and Technology the award of a visiting research fellowship.

\section{References}

1. Hillman R E, Dandliker P J and Barton J K 1997 Angew. Chem., Int. Ed. Engl. 362714

2. Dupureur C and Barton J K 1997 In Comprehensive supramolecular chemistry (ed.) J-M Lehn (New York: Pergamon) vol. 5, p. 295

3. Mesmaeker A K-D, Lecomte J-P and Kelly J M 1996 Top. Curr. Chem. 17725

4. Norden B, Lincoln P, Akerman B and Tuite E 1996 In Metal ions in biological systems: Probing of nucleic acids by metal ion complexes of small molecules (eds) A Sigel, H Sigel (New York: Marcel Dekker) vol. 33, p. 177

5. Sigman D S, Mazumder A and Perrin D M 1993 Chem. Rev. 932295

6. Murphy C J and Barton J K 1993 Methods Enzymol. 226576

7. Turro N J, Barton J K and Tamalia D A 1991 Acc. Chem. Res. 24332

8. Pyle A M and Barton J K 1990 Prog. Inorg. Chem. 38413

9. Tullis T D (ed.) 1989 Metal-DNA chemistry. ACS Symposium Series No. 402 (Washington, DC: Am. Chem. Soc.)

10. Barton J K 1986 Science 233727

11. Arounaguiri S and Maiya B G 1996 Inorg. Chem. 354267

12. Arounaguiri S, Dattagupta A and Maiya B G 1997 Proc. Indian Acad. Sci. (Chem. Sci.) 109 155

13. Arounaguiri S and Maiya B G 1999 Inorg. Chem. 38842

14. Perrin D D, Armango W L F and Perrin D R 1980 Purification of laboratory chemicals (Oxford: Pergamon)

15. Yamada M, Tanaka Y, Yoshimoto Y and Kuroda S 1992 Bull. Chem. Soc. Jpn. 651006

16. Chambron J-C, Sauvage J-P, Amouyal E and Koffi P 1985 Nouv. J. Chem. 9527

17. Vleck A A 1967 Inorg. Chem. 61425

18. Brustall F H and Nyholm R S 1952 J. Chem. Soc. 3570

19. Ablov A V 1961 Russ. J. Inorg. Chem. 6157

20. Goss C A and Abruna H D 1985 Inorg. Chem. 244263

21. Harris C M and Mekezie E D 1967 Inorg. Nucl. Chem. 291407

22. Pfeiffer P and Tapperman C Z 1933 Anorg. Chem. 215273

23. Lin C-T, Bottcher W, Chou M, Cruetz C and Sutin M 1976 J. Am. Chem. Soc. 986536

24. Sullivan B P, Salmon D J and Meyer T 1978 J. Inorg. Nucl. Chem. 173334

25. Hartshorn R M and Barton J K 1992 J. Am. Chem. Soc. 1145919

26. Amouyal E, Homsi A, Chambron J-C and Sauvage J-P 1990 J. Chem. Soc., Dalton Trans. 1841

27. Juris A, Balzani V, Barigelletti F, Campagna S, Belser P and von Zelewsky A 1988 Coord. Chem. Rev. 8485

28. Eranshaw A 1968 Introduction to magnetochemistry (London: Academic Press)

29. Reichmann M E, Rice S A, Thomas C A and Doty P 1954 J. Am. Chem. Soc. 763047

30. Kelly J M, Toss A B, McConnell D J and OhUigin C 1985 Nucl. Acid Res. 136017

31. Cohen G and Eisenberg H 1969 Biopolymers 845

32. Satyanarayana S, Dabrowiak J C and Chaires J B 1992 Biochemistry 319319

33. Carter M T, Rodriguez M and Bard A J 1989 J. Am. Chem. Soc. 1118901

34. Grover N, Gupta N, Singh P and Thorp H H 1992 Inorg. Chem. 312014

35. Maiya B G, Ramana C V, Arounaguiri S and Nagarajan M 1997 Biorg. Med. Chem. Lett. 7 2141

36. Mehta G, Muthusamy S, Maiya B G and Arounaguiri S 1997 Tetrahedron Lett. 407125 
37. Friedman A E, Kumar C V, Turro N J and Barton J K 1991 Nucl. Acids Res. 192595

38. Friedman A E, Chambron J C, Sauvage J P, Turro N J and Barton J K 1990 J. Am. Chem. Soc. 1124960

39. Hiort C H, Lincoln P and Norden B 1993 J. Am. Chem. Soc. 1153448

40. Ackermann M N and Interrante L V 1984 Inorg. Chem. 233904

41. Turro C, Bossman S H, Jenkins Y, Barton J K and Turro N J 1995 J. Am. Chem. Soc. 117 9026

42. Dupureur C M and Barton J K 1994 J. Am. Chem. Soc. 11610286

43. Hartshorn R M and Barton J K 1992 J. Am. Chem. Soc. 1145919

44. Jenkins Y, Friedman A E, Turro N J and Barton J K 1992 Biochemistry 3110809

45. Lerman L S 1961 J. Mol. Biol. 318

46. Neyhart G A, Grover N, Smith S R, Kalsbeck W A, Fairley T A, Cory M and Thorp H H 1993 J. Am. Chem. Soc. 1154423

47. Barton J K, Danishefsky A T and Goldberg J M 1984 J. Am. Chem. Soc. 1062172

48. Gupta N, Grover N, Neyhart G A, Liang W, Singh P and Thorp H H 1992 Angew. Chem., Int. Ed. Engl. 311048

49. Carlson D L, Huchital D H, Mantilla E J, Sheardy R D and Murphy W R Jr 1993 J. Am. Chem. Soc. 1156424

50. Pyle A M, Rehman J P, Meshoyer R, Kumar C V, Turro N J and Barton J K 1989 J. Am. Chem. Soc. 1113051

51. Harbour J R, Chow V and Bolton J R 1974 Can. J. Chem. 523549

52. Tan J D, Hudson S E, Brown S J, Olmstead M M and Mascharak P K 1992 J. Am. Chem. Soc. 1143841

53. Orellana G, Mesmaker A K-D, Barton J K and Turro N J 1991 Photochem. Photobiol. 54499

54. Stemp E D, Arkin M R and Barton J K 1997 J. Am. Chem. Soc. 1192921 